\title{
Multiple Responses through Verbal Discourse in the Reading
}

\author{
of Literary Texts \\ Malachi Edwin Vethamani \\ School of Education, Languages and Communication, Wawasan Open University \\ Kuala Lumpur Malaysia \\ Tel: 60-3-9281-7323 E-mail: mevethamani@gmail.com \\ Premalatha Nair \\ English Department, International Languages Teacher Training Institute \\ Lembah Pantai, Bangsar, Kuala Lumpur, Malaysia \\ Tel: 60-16-381-4735 E-mail: premi33@yahoo.com
}

\begin{abstract}
The past decade has viewed the important role literature plays in enhancing the learning process among students in Malaysian English classrooms. However, most English teachers in particular are not prepared to teach literature due to the lack of training and exposure on the subject. This paper seeks to explore the ways teacher trainees from one teacher training institute attempt to provide multiple responses on two Malaysian short stories through verbal discourse. This qualitative study uses the transcripts from the audio recorded discussion among dyads to analyze the ways subjects respond to two short stories. Using a constant comparative method, recurring themes were lifted based on Newell's (1996) typology of responses. The findings of this study revealed that the subjects used four different types of responses, namely associations, interpretation, personal response and evaluation. These responses describe the subjects' maturity in relating their understanding of the literary texts besides the capability of making critical judgments and rationalization.
\end{abstract}

Keywords: Multiple responses, Literary texts, Meaning

\section{Introduction}

One of the most significant current discussions in the educational field is the role literature plays in enhancing students' learning. The importance of literature is debated by various stakeholders, namely, the teachers and parents at large. Since the incorporation of the Literature in English component in the English language subject in 2000 in secondary schools, English language teachers have accepted the role literature plays with mixed feelings. Often, not knowing how to approach literary studies in class, teachers treat teaching literary texts as another reading comprehension lesson (Vethamani, 2004). This has led students merely seek for information and memorize it for examination purpose. This impedes learners' personal engagement and multiple interpretations of texts which are crucial for the study of literature (Purves \& Rippere, 1968). Hence, the aim of implementing literature in English component remains unfulfilled.

Vethamani (2004) urges for the rectification of the situation since the study of literature does not only focus on mere literal comprehension but the need to enjoy and experience them as well. Teachers who attempt to teach literature as a comprehension text impede students 'multiple interpretations' which are crucial in the study of literature. Quite often, these teachers seek for the one definite answer intended by the author of the literary work. This is one of the reasons why students find difficulties in making out the meaning of the literary works. What they failed to realize is that learning literary texts differ from other genre that normally requires factual information. Rosenblatt (1982) distinguishes the difference in terms of the emphasis placed by learners as they read. According to Rosenblatt (1982), learners might attempt to seek for factual information to be highlighted for examination purposes. This is known as the 'efferent stance' of reading (p.269). This is one common academic behavior emphasized in the Malaysian schools as a license to further their studies in higher institutions.

Another concern deals with the 'correctness' of the interpretation of the literary works. Learners generally avoid participating in a literary classroom for fear of giving the wrong interpretation. What they failed to realize is that 'correctness' should not be seen as a warrant for understanding literary texts. Misinterpretation by learners should be seen as a necessary part of reading that contributes to the learning process (Purves, 1988). This allows learners to create their own meaning of the literary works based on their own understanding. Learners' version of the interpretation should be seen as legitimate since it involves their personal engagement with the text (Iser, 1978). Therefore, there is a need 
to allow learners to reflect their own literary experiences through literary works and to allow for multiple interpretations of the texts to take place. Based on these views, this paper seeks to look into ways learners attempt to achieve multiple responses from a dialogic discourse of literary text. This is seen as a crucial aspect in the study of literature in Malaysian context since no studies have look into the ways learners' respond to literary works.

\section{Literature Review}

A considerable amount of literature has been published on literary study. These studies have highlighted the important role literature plays in the enhancement of learners' knowledge. Earlier studies on literature focused on readers' role in literary experience. Richard's (1929) investigation on students' responses to poems identified among others their incapability of responding to the texts. For example, they relied heavily on already established critical opinions. On the other hand, Squire (1963) focused on the types of responses students produce when they read short stories. The author divided each short story into several parts and asked the students to read each section. This was followed by interview sessions to seek the types of responses students produced. The analysis of this study yielded seven categories of responses: literary judgment, interpretational, narrational reactions, associations, self-involvement, prescriptive judgment and miscellaneous. Other researchers have also attempted similar studies and identified several categories of responses. Among them, Purves and Rippere (1968) identified four categories for analyzing the content of responses through written responses: engagement, perception, interpretation and evaluation. These categories were further developed and expanded by Odell and Cooper (1976). Based on written responses on three novels by first grade above average students, four categories were identified by the researchers. These categories were similar to the ones proposed by Purves and Rippere (1968) but were refined by adding sub-categories. These are personal statements (about the reader and the work), descriptive statements (narrational and descriptive of aspects of the work), interpretation (parts of the work and the whole work) and evaluation (about evocativeness construction and meaningfulness of the work).

A similar approach was also adopted by Newell (1996) by using writing tasks to analyze students' responses to a short story. Forty-five $10^{\text {th }}$ grade students were assigned to either reader-based or teacher-centered instructional tasks. The students wrote analytic essays responding to the short stories and completed three post-tests of story understanding. The results of the study indicated that students who received reader-based tasks attained higher post-test scores compared to students who received teacher-centered instructional tasks. Newell (1996) further identified six literary response statements which were similar to the ones identified by earlier researchers such as Odell and Cooper (1976), Purves (1985) and Squire (1963). The six types of statements are: descriptive (retelling of story and description of aspects), personal reaction (reaction to form and content), associative (references to writers' experiences and knowledge), interpretive (statements that go beyond what are found in the story and inference is made), evaluative and miscellaneous.

Probst's (2004) metaphor 'to build on shifting sands' best describes the way literature is approached in the Malaysian schools. Teachers are trying their best to deliver their lessons and students are straining their memory power to digest what is imparted in the classroom. This resulted in the lack of critical judgment and respond on the students' part.

The emphasis on memorizing facts for the examination purpose further hinders students' capability of using their thinking power to make evaluation and judgments. Bleich (1975) cautions for the need to read literary text in the form of a response for learning to take place. Furthermore, delivering personal response of literary works is not an academic behaviour taught by teachers to their students. Hence, there is a need to view literary texts through the aesthetic stance. The aesthetic stance requires learners to respond by using their 'lived-through' experiences with the short stories (Rosenblatt, 1983, p. 286). It focuses on subjects' perception through the senses, feelings and intuition (Rosenblatt, 1988).

Reader response is very much focused on students' responses to the text read that involves relating to their prior knowledge and personal experiences. Since these responses are 'individual and multifaceted', the end product results in various interpretations by different learners (Barr \& David, 1996, p. 453). Mellor and Patterson (2000) believe that it is more productive knowing how and for what purpose each interpretation is constructed. This will enable learners to grasp a stronger understanding of the issues highlighted and relate them to their surroundings.

Unfortunately educators' emphasis on efferent stance in reading literary texts limits students' comprehension to merely searching for facts to satisfy the needs of the exam-oriented curriculum. Therefore, there is a need to balance between efferent and aesthetic stances to enable students to connect their experience of the real world to the literary texts.

Reader response theory can meet the needs and goals of the Malaysian National Educational Policy (MNEP) if students are allowed to see the values and significance of reading literary texts. MNEP emphasizes the need to produce individuals who are 'intellectually, spiritually, emotionally and physically balanced and harmonic, based on a firm belief in and devotion to God' (KBSM, 2003). These aspects highlighted by MNEP are seen necessary in order to produce knowledgeable and competent Malaysian citizens which can be attained through learning literature. Reading literary texts is a journey towards self understanding. This can be achieved through the process of discovering various themes 
that highlights the significant human issues. Indirectly, the reading process shapes their thought and gives a clearer view of the real world itself. This will guide the learner to be a better person who can reason between good and bad based on their social norms and cultural values.

The study on readers' response gained much attention after Rosenblatt (1970) introduced the transactional theory of reader response. She places the reader as an important factor in creating meaning of the literary text. The text consists of printed words by the author and is seen as a lifeless form. It is the reader who brings life to the text by relating the printed words to their experiences as shown in Figure 1. This allows for the negotiation of meaning to take place between the author and the reader, hence the transaction takes place where learners attempt to make their own judgment from their experiences and prior knowledge. This results in a new meaning understood by the reader. The learners' interpretation is seen crucial in the reader response theory that confers value on the text (Burnard, 1998). Rosenblatt (1982) addresses a few factors that support the emphasis on readers in creating their own meaning. Literature is viewed as a reflection of the real world. This allows for the reader to have their own perception of the real world based on their surrounding and experiences. Furthermore, different cultural background may influence the perception of the reader. Hence, multiple interpretation of the literary texts should be valued.

Iser (1978) proposes that literary works consist of gaps where learners are required to fill those gaps based on their understanding. Similarly, real life situation also consist of gaps or uncertainty which are not easily understood. Learners resort to fill these gaps with their experiences, values and beliefs. This leads to a variation of interpretation by different readers since different students react differently due to their background experiences (Anderson, 1991). Therefore, educators should forgo uniformity of interpretation among their students. Based on the framework described in this section, this study focuses on how teacher trainees respond to local short stories using Rosenblatt's reader response theory. Particularly, the study highlights teacher trainees' use of prior/personal experiences in providing multiple interpretations of the read texts.

\section{Methodology}

This study is qualitative in nature where teacher trainees' responses to two short stories were recorded through verbal discourse. The primary data collection consisted of dyads' recorded discussions on two local short stories. Each subject was given a week to read each short story followed by an audio recording session where the dyads will record their discussions of the two short stories. A comprehension evaluation sheet was used as a guideline for the subjects reading process (refer to Table 1). During the audio recording session, subjects were asked to discuss the short story by using a set of questions given by the researcher as a guideline (refer to Table 2). The recorded conversations were transcribed verbatim to identify the multiple responses of the subjects.

\subsection{Subjects}

The subjects consisted of 96 teacher trainees from one teacher training institute in Kuala Lumpur. These trainees were enrolled for a B.Ed (TESL) degree programme and were in their second semester of their study. Literature was one of the components taught in the subjects' foundation programme. Furthermore, they were familiar with the literary component since they have studied literature in the secondary school. These subjects were paired at random to form dyads for the discussion sessions.

\subsection{The Texts}

The study focused on two local short stories that shared similar theme which is on poverty. The first short story is 'Just a Girl' by Lee Kok Liang. This story surrounds on a traditional Malay setting. The state of poverty of one family is highlighted. The parents are burdened with a blind daughter and contemplate to send her away since they could not afford to look after her. The protagonist feels lonely and are longing for love. Her obsession with the moon becomes intense when she hears that the moon is lovely and kind. The story ends with the girl walking into the river in search of the moon.

The second short story 'Journey' is written by Shirley Lim. This story focused on a young protagonist from a poor family background. Her burden is highlighted when she has to buy medicine for her ailing mother. The protagonist's dilemma is further intense with the irresponsible father who spends money gambling with his friends. The story ends with the protagonist crying alone at night thinking of her fate.

The two short stories were selected for this study for various reasons. First, both stories reflect the culture the students are familiar with. Second, both stories focus on a young protagonist which students can relate to. Third, these stories require inferencing from the reader since they consist of gaps which entail critical thinking and interpretation by the reader. Since both stories have open-ended endings, readers' understanding and interpretation are tested based on their experiences and their ability to think critically.

The reasons mentioned above are seen necessary since one of the goals of the NEP is to produce life-long learners with high moral standards. This can be materialized if the selected texts allow for critical thinking to take place. Furthermore, 
by introducing local texts, learners will be able to relate to their surroundings that allow for reasoning and justification to take place.

\subsection{The Procedure}

There were two steps involved in the collection of data for this study. In the first step, the subjects were given the first short story 'Just a Girl' by Lee Kok Liang. They were required to read the story and make notes a week before the recording session to familiarize the content. The audio recording session was conducted with each dyad discussing the story and allowing them to view their opinions. No time limit was set for the session. The same procedure was repeated for the second short story 'Journey' by Shirley Lim. The audio recording sessions were necessary to allow the researchers to gain students' multiple responses of the two short stories. The transcripts from the recorded discussions were obtained and analyzed. Using the constant comparative method, recurring patterns of aesthetic clusters were identified and labeled accordingly based on the six types of responses proposed by Newell (1989). However, only four types of responses were identified from the transcripts; associations, interpretation, personal response and evaluation. Table 3 shows an example of each type of responses found in the transcripts.

\section{Findings}

The findings of this study revealed the evidence of subjects' multiple responses by using four variations of aesthetic clusters. They are associations, interpretative statements, personal reactions and evaluation. These are discussed with examples in the section that follows.

\subsection{Associations}

Making association refers to the experiences and knowledge used as examples or illustrations of ones' understanding of the text (Newell, 1996). The subjects attempted to associate their understanding in various ways. This was achieved by using prior knowledge, personal experiences or intertextuality.

\subsubsection{Prior Knowledge}

Subjects attempted to comprehend the text through prior knowledge. For example, excerpt 1 shows how the dyad unfolds a complicated phrase. The phrase 'her other body leaves' (line 5) seems illogical to be accepted by most readers without prior knowledge of the culture portrayed in the text. Dyad B's explanation based on her knowledge of her belief allowed dyad A to gain understanding to the complicated phrase. Similarly in excerpt 2, dyad A highlighted the word 'herbs' and was not sure of its' significance in the story. Dyad B uses her prior knowledge on her cultural belief and suggested that herbs could refer to a kind of medicine used to terminate pregnancy (line 4). She rationalized her answers by stating that the protagonist's mother could resort to abortion due to her state of poverty (line 9).

\section{Excerpt 1}

1 A For me I think erhm here this story, I find it interesting because erhm I

found out something about the Muslim's belief where when you sleep you

guys believe that right?

2 B Yeah, when we Muslim sleep, we believe that the soul the spirit like fly away from

3 A Like leave the body.

4 B Yeah like leave the body and will return back in the morning when we woke

up. That's why we we like erh say erh we have the prayer to say thanks to

god that we are still alive in the morning.

5 A This one right? When night she felt sleepy now. And then she knew her other body leaves, I think erh that's what it means.

Excerpt 2

1 A No idea about it. Maybe some herbs.

2 B Herbs or whatever. I think its some 'chung yeoh' something like thatlah.

3 A Some herbs. Twigs twigs and leaves.

4 B Herbslah. Cos like you know in Mandarin we have this Cantoneselah. (chung yeoh) is like if they eat it, sure they miscarry the baby one you know?

5 A Is it true?

6 B Yeah its something, its like herbs. I don't know people whether they are 
still using this medicinelah but its like if you ate it too much, the baby

will you will miscarry your baby. Something like thatlah.

7 A Maybe maybe she wanted to abort the baby because

8 B Because like birth controllah. Too many to many siblings, right? Too many children she has.

9 A And they are poor. Only have salted soup and fish to eat. Oh god I can't imagine that happening.

These examples indicate the maturity level of the dyad in connecting their prior knowledge of the issue discussed and relating them to make sense of the literary text. Making connections between what was discussed and personal experiences and perspectives is said to enhance learning comprehension and retention (Ballenger, 1997). Furthermore, talking about literature among peers has its benefits where learners are able to get insights, visions and views of the world perceived by their peers, hence leading to shared knowledge (Koay \& Chiu, 1998).

From the examples given above, association is one form of aesthetic response from the subjects that associate or compare the issues or the characters of the short stories to subjects' experiences or prior knowledge. This allows subjects to move from interpretation of their experiences to reasoning out their understanding of the short stories. Furthermore, Rosenblatt (1970, pp. 30-31) views the reading of literature as bringing in 'personality traits, memories of past events' and 'present needs' for the understanding of the stories.

\subsubsection{Use of intertextuality}

Intertextuality is another form of aesthetic cluster utilized by subjects to enhance comprehension. Intertextuality is a process of understanding current texts by means of previous texts (Wink \& Putney, 2002, p. 132). This is evident in the subjects' discussion where they connected a previously learnt story to relate to the story being discussed. Examples of the use of intertextuality are shown in excerpt 3.

Subject A in excerpt 3 are questioning the significance of the title 'Journey' to the protagonist. In order to solve this curiosity, subject B relates the title of this story to another story with the same title (line 5). Both subjects are able to evaluate by means of comparing the themes of both stories. They finally agree that these two stories do not share similar theme since the plot of the stories are different. Through intertextuality, these subjects are able to rationalize and make their own judgment on the meaning of the story.

\section{Excerpt 3}

1 A What's your thinking?

2 B Ha ha I'm thinking about some... I don't knowlah why the title is journey?

3 A It very this story ah the journey very different to the other the journey

4 B Catherine Lim

5 A Yeah but if according to your idea that this is about her growing up then there is a connection because the journey by Catherine Lim is actually about how Richard made his decision is it?

6 B Yeah

7 A That modern little traditional whatever

8 B Or maybe this journey it talks about how the how the girl

$9 \quad$ A Go and buy the medicine?

10 B Ah he he he

11 A Takkanlah they named the title after that. Hai not sure.

12 B Oh oh no no actually I think a how along along along her journey to buy the medicine she she saw many many many thingslah like a woman what ah? About the passengers about the its it villagers ah

13 A So journey is about how she grew up.

14 B That's a good one.

Subject B in excerpt 4 manages to compare the character in the current story with another character from a story read previously (line 8). This link occurs when both subjects are curious about why the authors for both the stories did not 
name their protagonists. Subject A manages to reason out by means of intertextuality that the author purposely introduced a nameless protagonist to depict the protagonist as only 'a simple' (line 7) and 'lonely' girl (line 8) .

Excerpt 4

1 A No names.

2 B I don't like story without names.

3 A Refer like that to the girl, the girl you know.

4 B Yeah. The girl is like a nobody, not important.

5 A Ah maybe that's what the author wants right?

6 B What?

7 A The story about a simple girl common, nobody knows. Its like a everyday life where can happen in real world.

$8 \quad$ B Same as Just a Girl , right? Nobody cared about her since she's just a simple girl, lonely, like this one.

The examples above show how the subjects were able to see the relevance of outside sources and relate them to the short story. This is one way subjects were able to explain their own understandings of the story. The process of making connections to intertextuality allows learners to organize and reconstruct their understanding of a story for themselves. This is one way transfer of learning occurred among the subjects. This is evident when learning in one situation influences that person's learning in another situation (Bigge \& Shermis, 2004, p. 211). This allows the subjects to integrate their new knowledge into their existing knowledge base, therefore allowing them to understand and remember it better.

\subsection{Interpretive statements}

Interpretive statements are associated with statements that go beyond what can actually be found in a story (Newell, 1996). This form of statement is usually based on inferences made from the text. Interpretive statements allowed subjects to not only understand what was between the lines but go beyond them. For example, in excerpt 5 , the subjects are discussing the significance of the personification 'skulls smiled without friendship' found in the short story. Subject A's interpretation of the dream to the harsh life of the protagonist leads her partner to assume that the protagonist's dream foreshadows what will happen to the protagonist's family (line 2). This allows subject B to infer that the dream could foreshadow the abortion carried out by the protagonist's mother and that the skulls personify the unborn child as stated in line 10 .

Excerpt 5

1 A Ah.... To take the parcel.....yeah, maybe ehrm can you imagine eh when you facing the a harsh life and you suddenly you ... cannot accept it then it goes into your dream a hah you dream about it a hah everyday and night.

2 B I think the dream symbolizes what will happen next. So that night she dreamed that she sees a lot of things such as

3 A Skulls

4 B Skulls smiles without friendship and looking around

5 A Quite scary

6 B Ah yeah. That's why a hah.

7 A Maybe maybe the skulls symbolize that the dream symbolizes that ah....her mother will have an abortion

8 B Yeah, skulls smiled without friendship ah....they never know each other but they still smiled

9 A Ahah, hah

10 B Its like a symbol of her the ..she will have brother but her brother will be unborn

In excerpt 6 , the dyad is discussing the reason for the protagonist's mother to bleed. Subject A's explanation is very detailed where she points out the protagonist's father as an irresponsible man, who has the habit of gambling, hence, neglecting his family. This leads the mother to take the sole responsibility towards the family (line 2). Therefore, subject 
A infers that the protagonist's mother went through an abortion due to poverty (line 4).

Excerpt 6

1 B So ah...why do you think her mother is bleeding?

2 A I think because you know her father his father loves to gamble, so for me a person who loves to gamble who loves to gamble you know doesn't have a work, they just know they just know, they just want to take money from people. If you if you see in movies eh.. I don't think in movieslah, I read if who if a if man..

3 B If a father

4 A Yeah if a father loves to gamble, for sure the family's condition is in you know in a ...its hard to say ..have a lot of difficulties, have a lot of problems because if a father loves to gambling to gamble gambling. Okay ah..probably a....most most of the man who loves gambling, okay, they are lazy at work and then they only know, if they are lazy, they only know to take money from their wife. So ah.. they become irresponsible okay and then ah.. the wife have to take..you know to take to take the you know to carry out eh responsibility responsibility

In excerpt 7 both subjects agree that the theme of the story could be on the women's role. They derive this point by inferring from some of the events that took place in the text. For example, subject B points out the fact that both the protagonist and her mother are women (lines 4 and 5) and carry heavy responsibility since they are 'overworked' (line 11). On the other hand, comparison is made to the male characters in the story where the brothers and father are seen playing (line 7). Both subjects came to the conclusion that the theme is about women's role in the society (lines 10 and 11).

\section{Excerpt 7}

1 A The theme

2 B The theme yeah

3 A Maybe about woman maybe

$4 \quad$ B Yeah because the girl and the mother both are

5 A Women

6 B The what women?

7 A The male characters in the story, the four brothers were playing in the street that's all they are doing. The father is playing the elder sister is the one looking after.

8 B Yeah

9 A The baby.

10 B Women, women's role

11 A Role in the society. The mother I think is overworked.

On the other hand, multitude of responses can also occur in different interpretation perceived by the subjects. For example, both subjects in excerpt 8 conveyed their different opinion on the theme of the short story. Subject A believes that the theme is 'about abortion' (line 3). She came to this conclusion by linking the author's background. On the other hand, subject B has a different view that the theme is referring to the protagonist's journey to maturity (line 10). She justifies her answer by stating the big role played by the protagonist in looking after her ailing mother (line 12).

\section{Excerpt 8}

$1 \mathrm{~A}$ : The theme. Okay, from the story that we shared just now, I think the

theme is about, yeah, when you woke up at night and you see your

mother bleeding, a...from an unknown location it seems like and

unknown parcel, when the what, background of Shirley Lim

2 B : Yes 
3 A: $\quad$ She's a social writer I think. She always writes about social life and everything, so, I think it's all about abortion, you now

Later

$10 \mathrm{~B}$ : Ah...okay, my theme, I think is different from you. I think the theme is ehm

is like being a matured girl when you are not ready. Being matured

matured girl. In this context a...the girl, a...had to take big

responsibilities, okay

$11 \mathrm{~A}: \quad$ Okay

12 B: From a...where she has to fetch the parcel like you said, okay then ehm

she when her mother was bleeding she's the okay, from what you have

said, now I know why why the mother was bleeding. She's bleeding from

the abortion and I think the parcel contains a ehm medicine. She has to like help

look after her motherlah.

From the examples above, the capability of the subjects to predict the possible outcome of the abortion reflects their ability to comprehend likely outcomes beyond the story. This ability was stressed by one of the subjects who admitted that discussion helped her to see beyond the printed words. Furthermore, interpretation based on inferences is crucial in literary studies since the nature of literature is full of riddles which Iser calls 'blanks' or 'gaps' which need to be filled in by readers $(1978$, p. 8). This is supported by Mercer $(2000$, p. 147) who believes that one way of achieving understanding is by making inferences through interaction. Hence, inferencing is one form of scaffolding that enabled subjects to understand the literary texts.

\subsection{Personal Reaction}

Subjects are also capable of providing personal reaction towards the characters found in the stories. For example, subject A views her personal reaction towards the protagonist's parents. She asserts that the parents 'should love her even if she is blind'. Subject A reacts to the story as if it is not fictional but happening in reality. She goes one step further by making a statement on how the character should act in line 3 .

\section{Excerpt 9}

1 B I think the theme is about social injustice.

2 A Why social? Because she is blind?

3 B No you see, the way the parents want to send her away. They should love her even if she is blind.

In excerpt 10 , subject B reacts personally towards the protagonist's father who is characterized as a lazy man in the short story. This leads subject B to emphasize the importance of a father's role 'as the leader' in a family by taking 'full responsibility' towards the family (line 1). Based on the personal reaction given by subject B, subject A suggests that 'a balance of responsibility between husband and wife' is essential for a happy family (line 2).

\section{Excerpt 10}

1 B I think yes. In my opinion, the man must lead. Is the leader of the family. And must take full responsible to take care and raise to take care of the children and erh help the children well raise up. And to help them get to school to get proper education, to get proper food and erh basically as the leader of the family must erh take full responsibility.

2 A So can we say that the story is trying to say that there should be a balance of responsibility between husband and wife?

3 B Ya, that's what I believe.

In excerpt 11, subject A's strong emotional feeling is expressed in lines 1 and 3 when she states that the protagonist's mother's reaction is immoral. She further gives a personal statement in line 3 when she states 'her mother should think first before she do something'. This personal statement on how people should act is identified as a 'personal reaction statement', where one reacts to the content of a text (Newell, 1996, p. 170). This is further supported by Miller and Dungwall (1997, p.290) who view literary discussion as crucial in 'developing students' self-conscious reflections'. 


\section{Excerpt 11}

1 A Since killing is one of the most heavy criminal and ah very unmoral

2 B Immoral

3 A Immoral thing. I think her mother should think first before she do something.

There are so many alternatives in order to solve a problem actually.

The assertion of personal reaction by the subjects in the literary discussion enabled them to see the relationships 'between the texts of their own lives and the lives of others who are like them as well as different from them' (Rogers, 1997, p. 109). The venting of personal feelings prompted by the short story played a prominent role in the subjects' responses to help them enhance the meaning of the story. Subjects were able to relate to the text in a truly empathetic manner. It also enabled subjects to relate to the real life. Loban et al., (1969) believe that literature gives a balanced perspective in which through different emotional responses, one may accept or reject the compassion offered by the literary text.

\subsection{Evaluation}

The ability of making evaluation of the story is evident among the dyads. For example, in excerpt 12, subject A manages to highlight an issue from the story which is on abortion. She stresses the illegality of abortion and that there should be another option available to solve the problems faced by the protagonist's mother. In excerpt 13, subject A focuses on the role of men in a family. She stresses that the author has highlighted the burden carried by women in raising a family and that men need to play an equal role, as well.

These two examples show how evaluation as a form of scaffolding was rendered by subjects to express their understandings of the short story. They took one step further by rendering their own opinions through critical thinking. This is evident when the subjects were able to evaluate the reactions of the characters from the story; hence, they were able to build their own sense of values.

Excerpt 12

1 A One thing that attract me and this attracted me from erh one point that had

attracted me from this text is wrhm the issue that had been brought her.

Whether it is erh whether it is the right thing to abort your children you're

your children lah erh if you are in

\section{Excerpt 13}

1 A Because the interesting part here is that the author is said that ah...

2 B Using indirect or direct I don't know lah. Like readers need to think and read

many times before you you can understand the whole whole story.

3 A The message here for me is that ah man must must be a be responsible.

Because in this story I found that her mother is the one who bring up the

children not not her father. So ah what I can say here is that a woman

should not woman should not take all the responsibility to to raise their

children but they have to share the responsibility that is the good example

for a happy family.

\section{Discussion}

Based on the transcription analysis, the aesthetic focus was prominent where these subjects related their experiences, previous knowledge and intertextuality to the texts. These enabled them to hypothesize and infer the possible outcomes of the story. Allowing participants to share their understandings of the literary works with their peers produce multiple responses. These responses are the result of the verbal discourse which is much concerned with the social aspect of the learning process. What is evident from the participants' discussion is the mature responses produced by relating to their personal experiences and knowledge. This is one evident that indicates subjects' intellectual capacity. Much research that have been conducted in the field of literature focus on how much learners take with them from reading literary works. This study shows that the learners have reached the state of maturity when their viewpoints are shifted from the unknown to the known. Their capability of reasoning and rationalizing their opinions have put them one step higher in the learning process which is emphasized in the MNEP.

The participants' literary competence is revealed when they are capable of evaluating issues highlighted in the story and 
relate them to their everyday lives. This is very much needed in the education system to produce life-long learners who will be productive in their workplace. The satisfaction gained by the subjects from discussing literary works is shown from their aesthetic responses. Incorporating subjects' personal reaction also allows them to express their emotions and make reflections. This is crucial in achieving high moral standards as reflected in MNEP.

One aspect that needs to be acknowledged by educators is the fact that response to literature is unpredictable and may change over time. Learners' experiences can alter their perspective over certain issues and this enables them to gain new knowledge from literary experience. Therefore, response to literature is a learned behaviour (Purves 1973).

The examples also show different interpretation are produced by different dyads in understanding the same context. These differences are the result of the depth of their experiences and prior knowledge towards the issues highlighted and their capability of making critical evaluation of the issues.

This study has attempted to look at the ways teacher trainees respond to two short stories. Their multitude responses give a new perspective in the study of literature in the Malaysian classrooms.

\section{Implications and Conclusions}

This study suggests the need for educators to create an environment for the students to express their understanding of literary works. For example, discussions in the classroom should be encouraged by allowing every student to participate in the discussion. Educators also need to allow peer discussion to be carried out in the classroom since peers can also contribute in the learning process. Students' multiple responses should be seen as a healthy learning process. It is not the question of how learners read that needs to be focused on. Instead, teachers should address the ways learners communicate with literary works.

As the study of literature is emphasized by the Ministry of Education (MOE), there is a need to reconsider the ways literature is approached in the classroom. The guiding principle should focus on the transaction that occurs between the reader and the text as proposed by Rosenblatt (1970). This will allow educators to reflect on their students' capability of expressing themselves and making judgments through various issues highlighted in the literary works. Indirectly, the learning process transcends beyond the four walls of the classroom where students will be able to relate what they have learnt to the current issues globally.

\section{References}

Anderson, L. (1991). Using reader-response theory in the introductory literature classroom. College Literature, 18(2), Academic Search Premier database (9603085683).

Marshall, J. D. (2000). Research on response to literature. In M. L. Kamil, P. B. Mosenthal, P. D. Pearson, \& R. Barr (Eds.), Handbook of reading research (vol. 3, pp. 381-402). Mahweh, NJ: Erlbaum.

Beach, R. \& Hynds, S. (1996). Research on response to literature. In R. Barr, M. L. Kamil, P. B. Mosenthal \& P.d. Pearson (Eds.), Handbook of Reading Research, (vol. 2, pp. 453-489). Lawrence Erlbaum Associates

Burnand, L. (1998). On the hermeneutic implications of text encoding. [Online] Available: http://users.ox.ac.uk/ lou/wlp/herman.html (December 12, 2007).

Ballenger, C. (1997). Social identities, moral narratives, scientific argumentation: Science talk in a bilingual classroom. Language and Education, 11(1), 1-14.

Bigge, M. C. \& Shermis, S. (2004). Learning theories for teachers. NY: Pearson Education.

Bleich, D. (1975). Reading and feelings: An introduction to subjective criticism. Urbana, IL: National Council of Teachers of English.

Iser, W. (1978). The act of reading. London: Routledge \& Kegan Paul.

KBSR. (2003). Year 4 English curriculum specification. Kuala Lumpur: Dewan Bahasa dan Pustaka.

Kooy, M. \& Chiu, A. (1998). Language, literature and learning in the ESL classroom. English Journal, 78-84.

Liang, L. K. (1994). Just a Girl. In L. Fernando (Ed.), Twenty-two Malaysian stories (pp. 97-105). Singapore: Heinemann Asia.

Lim, S. (1994). Journey. In L. Fernando (Ed.), Twenty-two Malaysian stories. (pp. 106-112). Singapore: Heinemann Asia.

Loban, W., Ryn, M. \& Squire, J. R. (1969). Teaching language and literature: Grades seven-twelve. NY: Harcourt Brace Jovanovich Inc.

Mellor, B. \& Patterson, A. (2000). Critical practice: Teaching "Shakespeare." Adolescent \& Adult Literacy, 43(6), 508-517.

Mercer, N. (2000). Words and minds: How we use language to think together. London: Routledge. 
Miller, G., \& Dingwall, R. (Eds.). (1997). Context and method in qualitative research. London: Sage Pub.

Newell, G. E. (1996). Reader-based and teacher centered instructional tasks : Writing and learning about a short story in middle-track classrooms. Journal of Literacy Research, 28(1), 147-172.

Odell, L. \& Cooper, C. R. (1976). Describing responses to works of fiction. Research in the Teaching of English, 10, 203-225.

Probst, R. E. (2004). Response and analysis: Teaching literature in secondary school. NH: Heineman.

Probst, R.E. (1999). Reader response theory and the problem of meaning. Publishing Research Quarterly, 8(1), Communication \& Mass Media Complete database (9701104664).

Purves, A., \& Rippere, V. (1968). Elements of writing about a literary work: A study of response to literature. Urbana, IL: NCTE

Richards, I. A. (1929). Practical criticism. NY: Harcourt Brace.

Rogers, T. (1997). No imagined peaceful place: A story of community, texts and cultural conversations in one urban high school classroom. In T. Rogers, \& A. Soter (Eds.), Reading Across Cultures: Teaching Literature in a Diverse society, NY: Teachers College Press.

Rosenblatt, L. M. (1970). Literature as exploration. London: Heinemann.

Rosenblatt, L. M. (1982). The literary transaction: Evocation and response. Theory into Practice, 21(4), $268-277$.

Rosenblatt, L. M. (1988). Writing and reading: The transactional theory (Tech. Rep. No. 13). Champaign: U of IIIinois, Center for the study of reading. [Online] Available: http://www.Writingproject.org/downloads/csw/TR13.pdf (June 6, 2006).

Squire, J. R. (1963). The responses of adolescents to four short stories. Urbana, IL: National Council of Teachers of English.

Vethamani, M. E. (2004). Developments in teaching of literature in English. Serdang: UPM Press.

Wink, J. \& Putney, L. (2002). A vision of Vygotsky. Boston: Allyn and Bacon.

Table 1. Comprehension Evaluation Sheet (Adapted and modified from Cattell, 1999)

\begin{tabular}{|c|c|}
\hline $\begin{array}{l}\text { Characters } \\
\text { Name the protagonist. } \\
\text { Comment on other characters and the way the } \\
\text { author presents them to the reader. }\end{array}$ & $\begin{array}{l}\text { Identify the protagonist's physical traits/ characteristics through; } \\
\text { - } \quad \text { The protagonist's words or actions } \\
\text { - } \quad \text { Narrator's words describing protagonist's } \\
\text { actions/thoughts } \\
\text { - } \quad \text { Other characters' reactions towards the protagonist. }\end{array}$ \\
\hline $\begin{array}{l}\text { Setting } \\
\text { Tells when/where the story happened }\end{array}$ & $\begin{array}{l}\text { Identify setting through; } \\
\text { - } \\
\text { - } \\
\text { - }\end{array}$ \\
\hline $\begin{array}{l}\text { Key images } \\
\text { Look for key images. Say what the image is, what } \\
\text { it means and how it works in the story. }\end{array}$ & Identify the literary elements used by the author. \\
\hline $\begin{array}{l}\text { Events (What happens) } \\
\text { Include all major events. Comment on any details } \\
\text { and incidents which you find interesting in the } \\
\text { story. }\end{array}$ & $\begin{array}{l}\text { Identify; } \\
\text { - } \quad \text { which event happened before/after another event. } \\
\text { problems/conflicts that occurred }\end{array}$ \\
\hline $\begin{array}{l}\text { Theme } \\
\text { What are the main ideas in the story? }\end{array}$ & Identify issues highlighted in the story. \\
\hline $\begin{array}{l}\text { Treatment of Conflict } \\
\text { Tells how problem was solved }\end{array}$ & $\begin{array}{l}\text { Identify; } \\
-\quad \text { how the problems/conflicts were solved. }\end{array}$ \\
\hline
\end{tabular}


Table 2. Questions for Discussion

1. Describe and discuss the characters found in the story you have read. Which character do you like/dislike? Give your reasons. Relate the character to your personal experiences if possible.

2. What are the problems faced by the protagonist? Support them with evidence from the text.

3. What are the issues highlighted in the story? Discuss the issues by giving your personal opinion.

4. Can you identify any literary techniques used by the author in relation to the story? Identify them and discuss the effectiveness of the techniques mentioned. Why do you think the author used these techniques?

5. Is the theme of this story similar to other stories you have read? Is it universal? Can you relate it to other cultures?

6. Do you like this story? Will you read it again? Give your personal opinion.

Table 3. Examples of responses

\begin{tabular}{|c|c|c|c|}
\hline & Types of responses & Examples & Rationale \\
\hline 1 & $\begin{array}{l}\text { Association } \\
\text { References to one's } \\
\text { experiences and } \\
\text { knowledge that is } \\
\text { used as examples or } \\
\text { illustrations }\end{array}$ & $\begin{array}{l}\text { B There're lots of technologies better than last } \\
\text { previous times, right? So we don't we do not seriously } \\
\text { believe in such } \\
\text { A Nonsense right? The black magic, the } \\
\text { mirror don't you think } \\
\text { B Ehm I wouldn't say I don't believe it } \\
\text { completely because you know I've } \\
\text { seen some thing similar yeah } \\
\text { A Ha ha. Okay where in Sabah? } \\
\text { B Yes. }\end{array}$ & $\begin{array}{l}\text { Dyad B associates her } \\
\text { understanding of black magic } \\
\text { through her prior experience. }\end{array}$ \\
\hline 2 & $\begin{array}{l}\text { Interpretation } \\
\text { Making inferences }\end{array}$ & $\begin{array}{l}\text { A Eh how you know the father is gambling } \\
\text { ah? } \\
\text { B You see the dice... } \\
\text { A Where? } \\
\text { B Dice means gamblinglah. }\end{array}$ & $\begin{array}{l}\text { Dyad B highlights 'dice' to } \\
\text { infer that the protagonist's } \\
\text { father is gambling. }\end{array}$ \\
\hline 3 & $\begin{array}{l}\text { Personal reaction } \\
\text { Engagement with the } \\
\text { story }\end{array}$ & $\begin{array}{l}\text { B I don't understand why the father is hot } \\
\text { tempered person. } \\
\text { A You know, I think he he is angry because } \\
\text { of poverty. He ah cannot afford to feed } \\
\text { his family. } \\
\text { B That is why the son ran away right? } \\
\text { A Yeah you know she is actually a victim due } \\
\text { to her blindness. But it's not her fault } \\
\text { to be blind, its not her fault to be blind. } \\
\text { She is innocent. }\end{array}$ & $\begin{array}{l}\text { Dyad A renders her personal } \\
\text { reaction towards the } \\
\text { protagonist by stating that it } \\
\text { was not her fault being blind } \\
\text { and that she is innocent. }\end{array}$ \\
\hline 4 & $\begin{array}{l}\text { Evaluation } \\
\text { Making judgment, } \\
\text { differentiate between } \\
\text { fiction and reality }\end{array}$ & $\begin{array}{l}\text { A What do you think of the mother? } \\
\text { B She should defend her daughter. It's not } \\
\text { her fault being blind, right? } \\
\text { A But in real life mothers don't send their } \\
\text { daughters away if they are blind right? }\end{array}$ & $\begin{array}{l}\text { Dyad B makes an evaluation } \\
\text { by relating the event from the } \\
\text { story to real life. }\end{array}$ \\
\hline
\end{tabular}




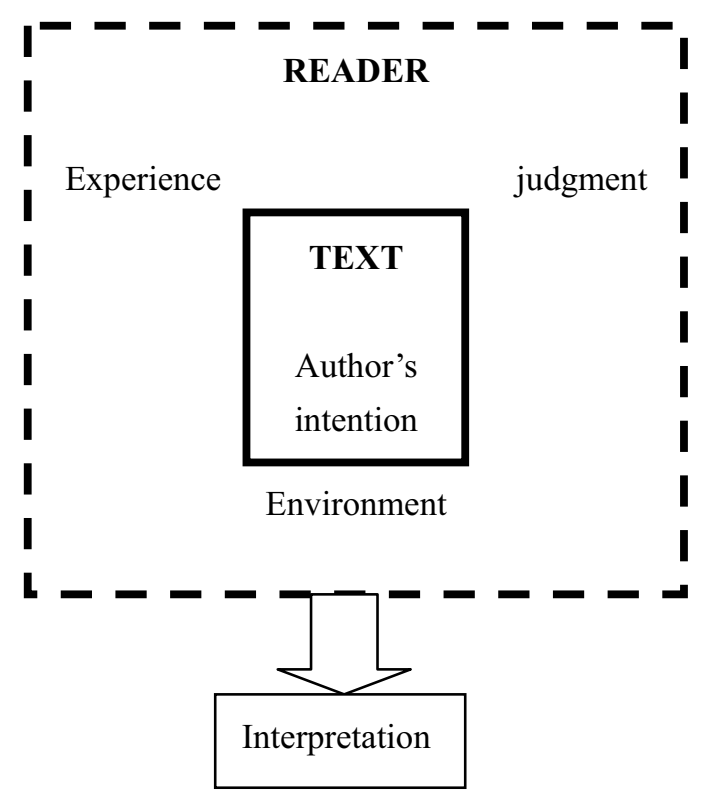

Figure 1. The Reader Response Process 